\title{
Converting enzyme inhibition and kidney function in normotensive diabetic patients with persistent microalbuminuria
}

\author{
MICHEL MARRE, HERVÉ LEBLANC, LEOBARDO SUAREZ, THANH-TAM GUYENNE, \\ JOËL MÉNARD, PHILIPPE PASSA
}

\begin{abstract}
The effects of a long term reduction in blood pressure on the kidney function of normotensive diabetic patients who had persistent microalbuminuria (30-300 $\mathrm{mg}$ albumin/24 hours) were studied in two groups of 10 such patients before and during six months of treatment with either $20 \mathrm{mg}$ enalapril or placebo daily. Treatments were assigned randomly in a double blind fashion. Before treatment both groups had similar clinical characteristics, weight, diet, total glycosylated haemoglobin, median albumin excretion rate (enalapril group $124 \mathrm{mg} / 24 \mathrm{~h}$, placebo group $81 \mathrm{mg} / 24 \mathrm{~h}$ ), and mean arterial pressure (enalapril group 100 (SD 8) $\mathrm{mm} \mathrm{Hg}$, placebo group 99 (6) $\mathrm{mm} \mathrm{Hg}$ ). During treatment weight, urinary urea excretion, and total glycosylated haemoglobin remained unchanged. The mean arterial pressure decreased in the enalapril group but not in the placebo group (enalapril group 90 (10) $\mathrm{mm} \mathrm{Hg}$, placebo group $98(8) \mathrm{mm} \mathrm{Hg}$ ). The median albumin excretion rate also fell in the enalapril group but not in the placebo group (enalapril group $37 \mathrm{mg} / 24 \mathrm{~h}$, placebo group $183 \mathrm{mg} / 24 \mathrm{~h}$.) The glomerular filtration rate rose in the enalapril group from $130(23) \mathrm{ml} / \mathrm{min} / 1.73 \mathrm{~m}^{2}$ to $141(24) \mathrm{ml} / \mathrm{min} /$ $1.73 \mathrm{~m}^{2}$, and total renal resistances and fractional albumin clearance decreased while fractional albumin clearance increased in the placebo group.

These results show that in patients who have diabetes but not hypertension a reduction in blood pressure by inhibition of converting enzyme for six months can reduce persistent microalbuminuria, perhaps by decreasing the intraglomerular pressure.
\end{abstract}

\section{Introduction}

In diabetic patients the long term vital prognosis can be blurred by kidney complications and excessive mortality from cardiovascular disease. ${ }^{12}$ The occurrence of microalbuminuria-that is, an albumin excretion rate greater than normal but less than that which gives a positive result with Albustix test strips-is a marker for kidney complications in type I diabetes ${ }^{3.6}$ and for both kidney and cardiovascular disease in type II diabetes. ${ }^{7}$

As a high albumin excretion rate in diabetes is of glomerular origin it may be due to either abnormal permeability of the glomerular membrane or increased glomerular perfusion pressure, or both. ${ }^{89}$ Diabetic nephropathy occurs after several years of chronic hyperglycaemia, ${ }^{10-12}$ which may modify the composition of the glomerular membrane. ${ }^{13}$ But though morphological changes in the glomeruli can be reversed by normal ambient glucose concentrations in rats ${ }^{14}$ and humans, ${ }^{15}$ the effects of strict metabolic control on the albumin excretion rate in type I diabetes are controversial..$^{16-20}$

Service de Diabétologie, Hôpital Saint-Louis, 75745 Paris Cedex 10, France MICHEL MARRE, MD, registrar HERVÉ LEBLANC, MD, registrar LEOBARDO SUAREZ, MD, research fellow PHILIPPE PASSA, MD, professor, chief physician

INSERM U36 75005 Paris, France

THANH-TAM GUYENNE, MD, senior registrar JOËL MÉNARD, MD, professor, chief physician

Correspondence to: Dr Marre.
On the other hand, aggressive antihypertensive treatment is an effective way of reducing the decline in the glomerular filtration rate of patients who have established diabetic nephropathy. ${ }^{21}{ }^{22}$ Microalbuminuria may be accompanied by a slight increase in blood pressure, ${ }^{23}$ and preliminary data suggest that early antihypertensive treatment can alter the albumin excretion rate of patients who have incipient diabetic nephropathy. ${ }^{24} 25$

Experiments on diabetic rats suggest that normal systemic blood pressure and increased glomerular capillary hydraulic pressure are simultaneously reduced by long term inhibition of converting enzyme and that this mechanism may prevent the increase in urinary albumin excretion that would otherwise occur. ${ }^{26}$. We therefore conducted a six month, randomised, placebo control, double blind study of diabetic patients who had persistent microalbuminuria but were not hypertensive to determine the effects of enalapril, a long acting inhibitor of angiotensin I converting enzyme, on the kidneys. Patients who had long standing diabetes and stable glycaemic control were selected. Enalapril was chosen because it is well tolerated and effective in insulin dependent diabetic subjects who have mild to moderate hypertension. ${ }^{27}$

Patients and methods

PATIENTS

The participants were selected from the 1500 diabetic patients who attended our clinic regularly. Two comparable groups of 10 patients each were picked using the following criteria: age 20-60; type I or type II diabetes known for at least five years; stable body mass index not exceeding $30 \mathrm{~kg} / \mathrm{m}^{2}$ albumin excretion rate $30-300 \mathrm{mg} / 24$ hours in at least two of three monthly measurements; supine blood pressure less than $160 / 95 \mathrm{~mm} \mathrm{Hg}$ on three consecutive monthly visits to the outpatient clinic; and no heart, kidney, liver, or systemic disease other than diabetes. The patients were not taking any drugs except for antidiabetic agents and, in the case of two women (cases 1 and 11), progestogen pills as contraceptives (the other women had intrauterine devices). All patients gave their informed consent to participate in the study, which was approved by the ethics committee of the Centre Hospitalo-Universitaire Lariboisière-Saint-Louis, Paris.

All type I diabetic patients were receiving insulin injections twice daily the four type II patients were receiving a special diet plus metformin and sulphonylureas. Table I lists the patients' individual characteristics at the start of the trial.

\section{STUDY PROTOCOL}

As the variability of the albumin excretion rate is high $^{28}$ the run in period lasted for three months, during which the inclusion criteria were assessed. At end of the run in period patients were studied for kidney function as described below. The patients were then randomly allocated in pairs to receive either $20 \mathrm{mg}$ enalapril maleate or its matched placebo daily for the next six months (the treatment period). Unmarked formulations were provided by Merck Sharp and Dohme (France), and the randomisation schedule was kept in the hospital pharmacy. The patients were followed up by the same investigator (MM). Neither the investigator nor the patients were aware of the type of treatment each patients was receiving in this double blind study.

The patients took the tablets every morning before breakfast. During both the run in and the treatment periods the systolic, diastolic, and mean arterial pressures, together with the body weight and albumin excretion rate, were measured every month, and the proportion of total glycosylated haemoglobin was measured every two months. At end of the treatmen period patients were again investigated for kidney function. In all cases the same antidiabetic treatment as that used before the study was maintained. 
BRITISH MEDICAL JOURNAL VOLUME $294 \quad 6$ JUNE 1987

The patients were instructed to follow a constant isocaloric diet (mean (SD) 2075 (255) $\mathrm{kca} / \mathrm{day} ; 50 \%$ carbohydrates, $35 \%$ lipids, $15 \%$ proteins) with no restriction on sodium intake.

\section{CLINICAL DETERMINATIONS}

The systolic, diastolic, and mean arterial pressures were measured every three minutes between 9 am and 11 am with an automatic device (Dinamap, Critikon, Florida, United States; cuff size $23-13 \mathrm{~cm} \times 13 \mathrm{~cm}$ ) while the patients were in the supine position. The mean of 10 measurements was recorded: the variation among measurements for single patients was $4 \%$.

The albumin excretion rate was measured in urine collected over the 24 hours before the visit to the clinic. A radioimmunoassay method ${ }^{29}$ was used (sensitivity $0.1 \mathrm{mg} / \mathrm{l}$; intra-assay and interassay variability $5 \%$ and $6 \%$, respectively). The mean (SD) albumin excretion rate of 30 age matched controls was $8 \cdot 1(8 \cdot 0) \mathrm{mg} / 24 \mathrm{~h}$ and the variability was $44 \%$. The course of the albumin excretion rate during treatment was calculated for each patient from the slope of albumin excretion rate by plotting albumin excretion rate values against time.

For determination of kidney function the patients arrived at the hospital having fasted at $7 \mathrm{am}$. Diuresis at $10-15 \mathrm{ml} / \mathrm{min}$ was induced by progressive renal plasma flow. In controls the mean glomerular filtration rate was 118 (8) $\mathrm{ml} / \mathrm{min} / 1 \cdot 73 \mathrm{~m}^{2}$ (variability $7 \%$ ) and the effective renal plasma flow 562 (72) $\mathrm{ml} / \mathrm{min} / 1.73 \mathrm{~m}^{2}$ (variability $10 \%$ ). The mean arterial pressure was recorded automatically every five minutes during clearance. The filtration fraction was calculated by dividing the glomerular filtration rate by the effective renal plasma flow (mean control filtration fraction $0.205(0.033)$ ), and the total renal resistances were calculated by dividing the mean arterial pressure by the effective renal plasma flow (mean control renal resistance $0.170(0.024) \mathrm{mm} \mathrm{Hg} / \mathrm{ml} / \mathrm{min})$. The serum albumin concentrations were measured by laser nephelometry. The fractional albumin clearance was calculated by dividing the urinary albumin clearance by the glomerular filtration rate (mean control fractional albumin clearance $\left.1 \cdot 17(0 \cdot 26) \times 10^{-6}\right)$. During clearance six consecutive measurements of plasma glucose concentration were performed with a glucose oxidase method and the mean value recorded.

The urinary sodium excretion and plasma potassium concentration were measured with flame photometry. The urinary urea concentration was measured with a urease method. On the day of assessment of kidney function $5 \mathrm{ml}$ blood was drawn, after the patient had been lying for two hours in the supine position, for direct immunometric measurement of active and total renin concentrations. ${ }^{32}$ The total glycosylated haemoglobin concentration was measured with a Cordis kit (mean control glycosylated haemoglobin $6 \cdot 1(0.5) \%$; intra-assay and interassay variability $4 \%$ and $6 \%$, respectively).

TABLE I-Clinical details of patients in study

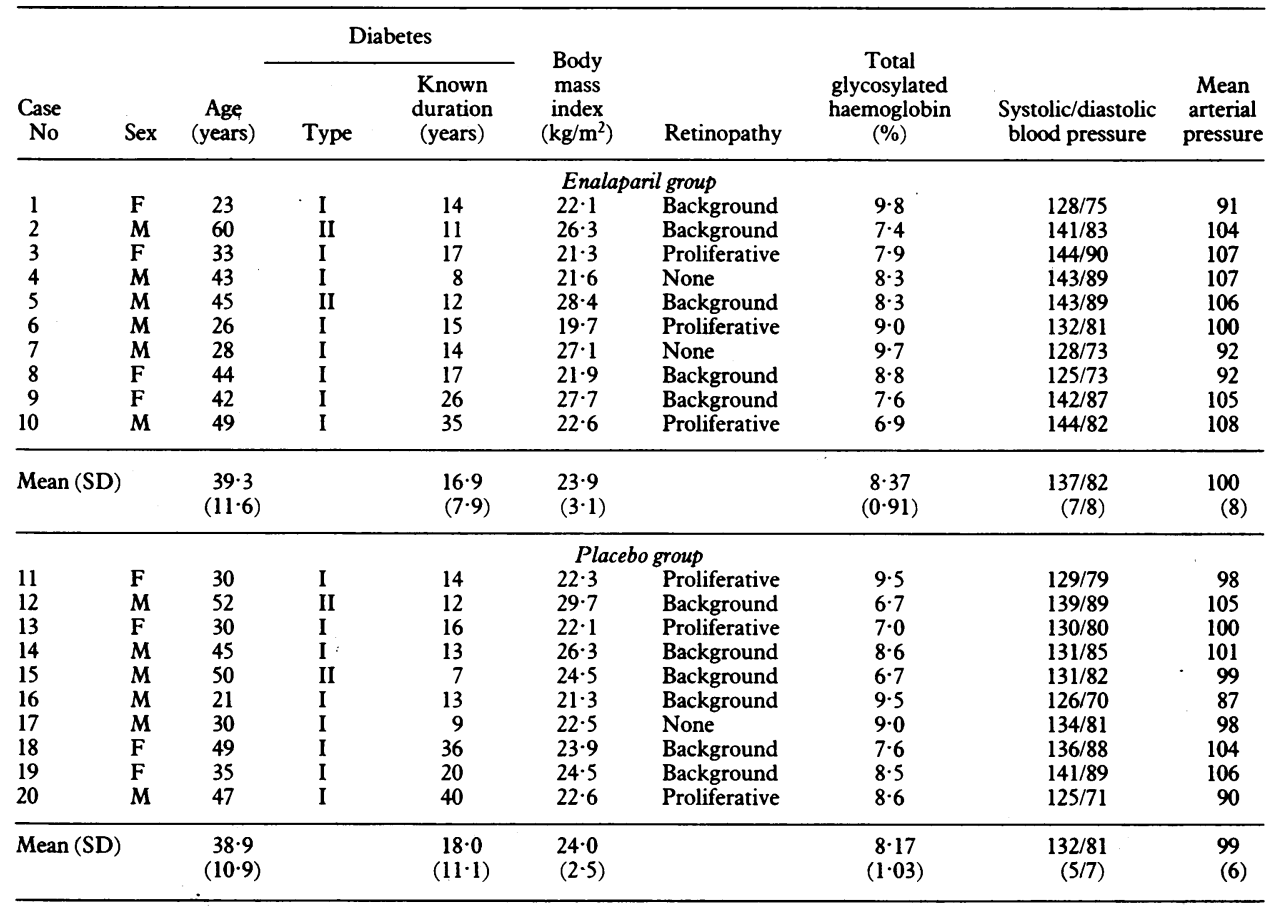

TABLE II-Mean (SD) concentrations of plasma glucose during clearance studies and serum potassium and urinary sodium and urea excretion at time of the kidney studies

\begin{tabular}{|c|c|c|c|c|}
\hline & $\begin{array}{l}\text { Plasma glucose } \\
(\mathrm{mmol} / \mathrm{l})\end{array}$ & $\underset{(\mathrm{mmol} / \mathrm{l})}{\text { Serum potassium }}$ & $\begin{array}{l}\text { Urinary sodium } \\
(\mathrm{mmol} / 24 \mathrm{~h})\end{array}$ & $\begin{array}{l}\text { Urinary urea } \\
(\mathrm{mmol} / 24 \mathrm{~h})\end{array}$ \\
\hline $\begin{array}{l}\text { Enalapril group }(n=10) \text { : } \\
0 \text { months } \\
6 \text { months }\end{array}$ & $\begin{array}{l}7 \cdot 2(2 \cdot 1) \\
7 \cdot 1(2 \cdot 3)\end{array}$ & $\begin{array}{l}4 \cdot 2(0 \cdot 4) \\
4 \cdot 1(0 \cdot 3)\end{array}$ & $\begin{array}{l}113(37) \\
109(30)\end{array}$ & $\begin{array}{l}294(152) \\
283(114)\end{array}$ \\
\hline $\begin{array}{l}\text { Placebo group }(n=10) \\
0 \text { months } \\
6 \text { months }\end{array}$ & $\begin{array}{l}7 \cdot 6(2 \cdot 4) \\
7 \cdot 8(2 \cdot 5)\end{array}$ & $\begin{array}{l}4 \cdot 0(0 \cdot 2) \\
4 \cdot 1(0 \cdot 3)\end{array}$ & $\begin{array}{r}105(31) \\
96(38)\end{array}$ & $\begin{array}{l}301(1174) \\
295(188)\end{array}$ \\
\hline
\end{tabular}

water loading, ${ }^{30}$ and patients remained supine when they were not voiding urine. After constant diuresis had been observed for at least one hour, the simultaneous clearances of iodine-125 iodothalamate and iodine-131 hippurate (Amersham Laboratories, Amersham) were calculated from primed infusions at a constant flow rate for two hours. ${ }^{31}$ These clearance values were calculated from six periods of 20 minutes and adjusted for a body surface of $1.73 \mathrm{~m}^{2}$. The ${ }^{125}$ I-iodothalamate clearance reflected the glomerular filtration rate, and the ${ }^{131}$ I-hippurate renal extraction measured the effective

\section{STATISTICAL ANALYSIS}

The values expressed are means (SD), except for the albumin excretion rate, which is shown as median and range values. These albumin excretion rate values were transformed into $\log _{10}$ for calculations because of their skew distribution. For the albumin excretion rate, mean arterial pressure, systolic and diastolic pressures, and total glycosylated haemoglobin a two way, repeated measured analysis of variance was used to assess the effects of time (within subjects) or group (between subjects) during both the run in and the treatment periods. ${ }^{33}$ Standard paired and unpaired $t$ tests were used for other calculations.

\section{Results}

CONTROL OF BLOOD PRESSURE AND METABOLISM (fig 1)

During the run in period the mean arterial pressure was comparable in the enalapril and placebo groups (100 $\mathrm{mm} \mathrm{Hg}(8) v 99$ (6) $\mathrm{mm} \mathrm{Hg}$, respectively. Thereafter, during the treatment period, it declined in the enalapril group compared with the placebo group (90 (10) $\mathrm{mm} \mathrm{Hg} v 98$ (9) $\mathrm{mm} \mathrm{Hg}$ respectively); time NS, treatment $\mathrm{p}<0.001$, analysis of variance; fig 1 . The 


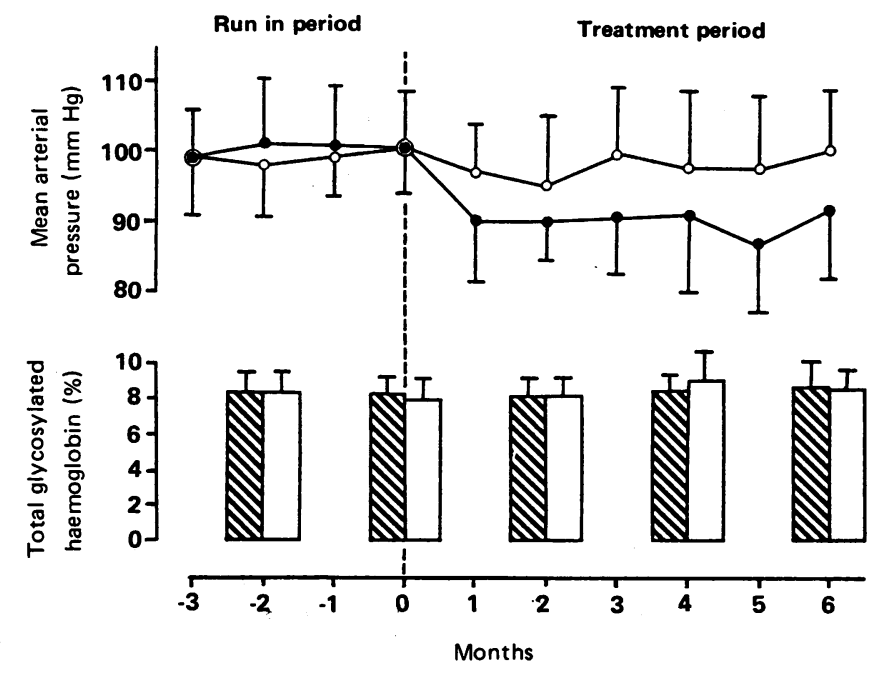

FIG 1-Mean arterial pressure and mean total glycosylated haemoglobin in enalapril group $(O, \mathbb{N})$ and placebo group $(O, \square)$ during run in and treatment periods. Bars represent SD.

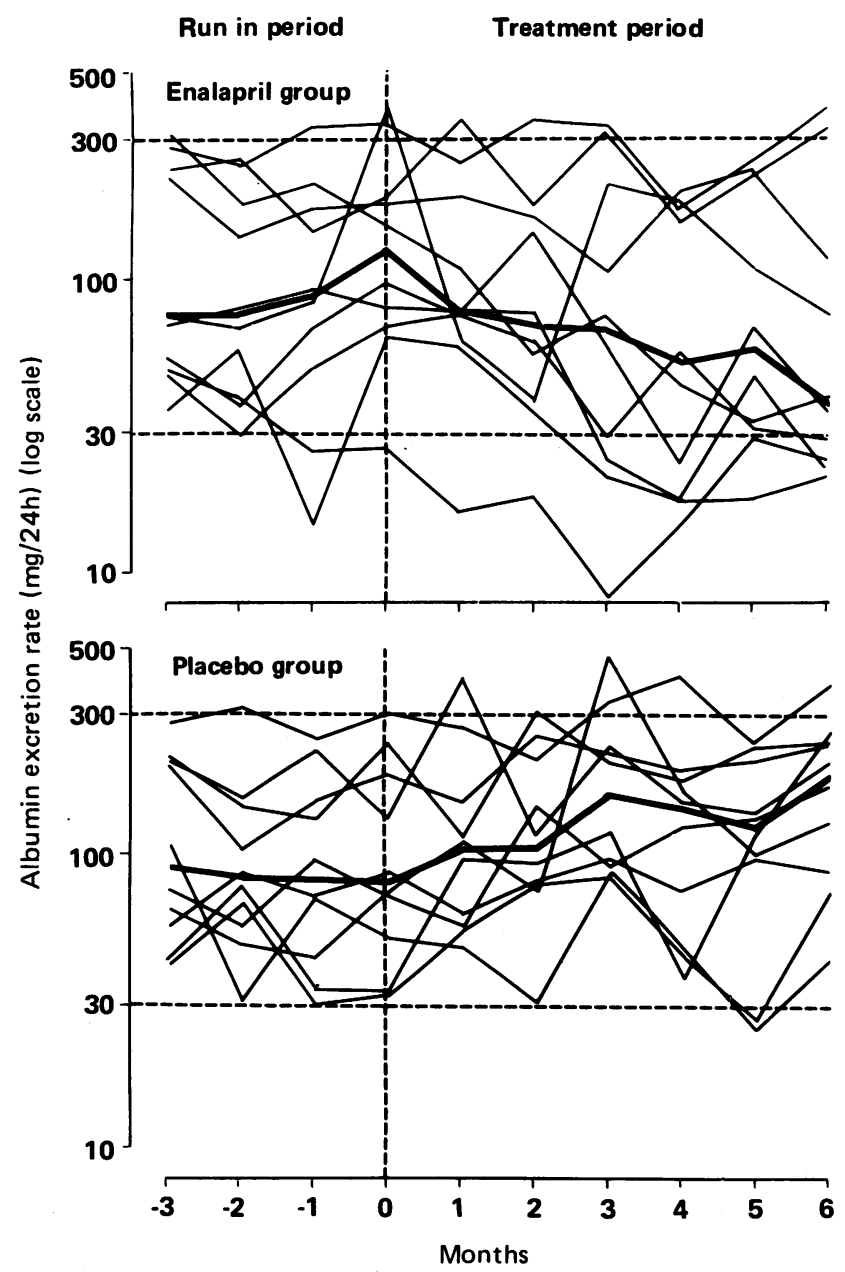

FIG 2-Individual albumin excretion rates in enalapril group (above) and placebo group (below) throughout study. Thick lines indicate median values.

systolic and diastolic pressures varied similarly from $137 / 82(7 / 8) \mathrm{mm} \mathrm{Hg}$ to $124 / 72(13 / 9) \mathrm{mm} \mathrm{Hg}$ in the enalapril group and from $132 / 81(5 / 7) \mathrm{mm} \mathrm{Hg}$ to $135 / 78(11 / 10) \mathrm{mm} \mathrm{Hg}$ in the placebo group.

The total glycosylated haemoglobin was $8.37(0.91) \%$ in the enalapril group and $8.17(1.03) \%$ in the placebo group during the run in period, and this remained steady thereafter (fig 1). The mean body weight was unchanged throughout the study; in the enalapril group it ranged from 67 (12) $\mathrm{kg}$ to 68 (12) $\mathrm{kg}$ and in the placebo group from 70 (14) $\mathrm{kg}$ to 70 (14) $\mathrm{kg}$. No side effects of the drug were recorded.

\section{COURSE OF ALBUMIN EXCRETION RATE DURING STUDY (fig 2)}

Figure 2 shows the albumin excretion rates for individual patients. During the run in period the variability of the albumin excretion rate for each individual patient ranged from $9 \%$ to $101 \%$ (mean $36 \%$ for enalapril group and $29 \%$ for placebo group). The variability and albumin excretion rate were comparable in both groups during the run in period. During treatment the median albumin excretion rate in the enalapril group varied from 124 (range $27-380) \mathrm{mg} / 24 \mathrm{~h}$ to 37 (21-382) $\mathrm{mg} / 24 \mathrm{~h}$ six months later and in the placebo group from $81(32-300) \mathrm{mg} / 24 \mathrm{~h}$ to $183(43-380) \mathrm{mg} / 24 \mathrm{~h}$ (time NS, treatment $\mathbf{p}<0.01$, analysis of variance). The mean progression of albumin excretion rate was $+6.2 \mathrm{mg} / 24 \mathrm{~h} /$ month $(95 \%$ confidence interval (CI) $-12 \cdot 8$ to $25 \cdot 2$ ) in the placebo group compared with $-7.9 \mathrm{mg} / 24$ $\mathrm{h} /$ month $(95 \% \mathrm{CI}-25 \cdot 5$ to $9 \cdot 7)$ in the enalapril group $(\mathrm{p}<0.005)$.

Enalapril group

Placebo group
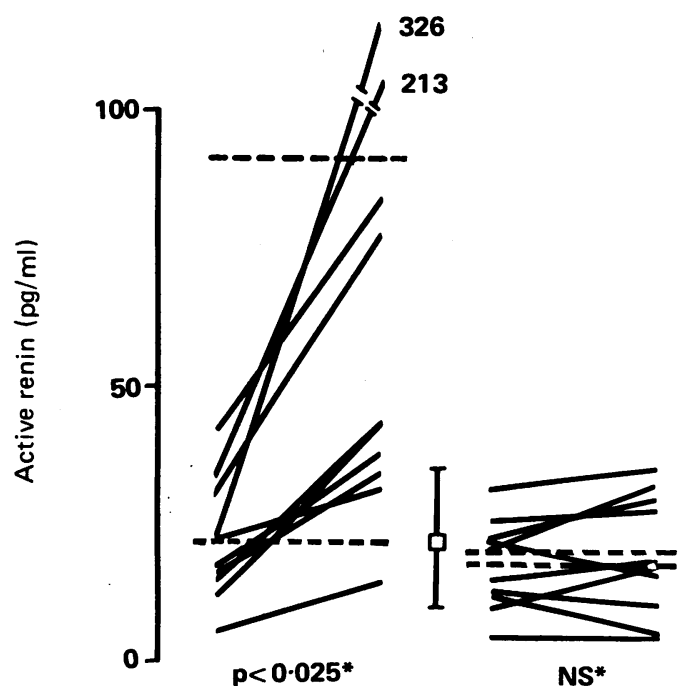

NS*

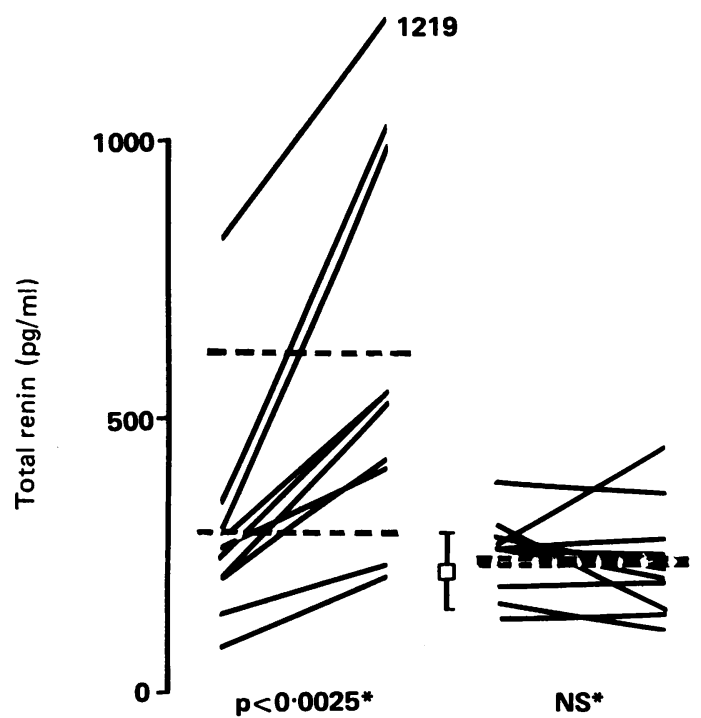

FIG 3-Individual plasma concentrations of active renin (above) and total renin (below) in enalapril group and placebo group before and after six months of treatment. $----=$ Mean values. $\square=$ Mean control value. Bars represent $2 \mathrm{SD}$. $\star$ Paired $t$ test.

\section{KIDNEY FUNCTION AFTER SIX MONTHS OF TREATMENT WITH} ENALAPRIL OR PLACEBO (figs 3 and 4)

Both groups had comparable mean plasma glucose and serum potassium concentrations and urinary sodium and urea excretions measured at time zero and six months (table II). In all patients who received enalapril the active and total renin concentrations increased significantly during treat- 8 ment, whereas no change was observed in patients who received placebo (fig 3). Figure 4 shows the individual glomerular filtration rates, effective renal 
plasma flows, total renal resistances, and fractional albumin clearances. In the enalapril group the glomerular filtration rate increased significantly from $130(23) \mathrm{ml} / \mathrm{min} / 1.73 \mathrm{~m}^{2}$ to 141 (24) $\mathrm{ml} / \mathrm{min} / 1.73 \mathrm{~m}^{2}(\mathrm{p}<0.005)$. In the placebo group a non-significant decrease from $133(26) \mathrm{ml} / \mathrm{min} / 1 \cdot 73 \mathrm{~m}^{2}$ to $127(25) \mathrm{ml} / \mathrm{min} / 1.73 \mathrm{~m}^{2}$ was seen. The initial effective rate plasma flow increased significantly in the enalapril group from $526(113) \mathrm{ml} / \mathrm{min} / 1.73 \mathrm{~m}^{2}$ to $581(128) \mathrm{ml} / \mathrm{min} / 1.73 \mathrm{~m}^{2}(\mathrm{p}<0.05)$, but not in the placebo group (597 (124) $\mathrm{ml} / \mathrm{min} / 1 \cdot 73 \mathrm{~m}^{2}$ to $602(15) \mathrm{ml} / \mathrm{min} / 1 \cdot 73 \mathrm{~m}^{2}$ ). The mean filtration fraction remained identical in the two groups at times zero and six months (enalapril $0.256(0.053)$ to $0.256(0.064)$; placebo $0.223(0.014)$ to 0.222 $(0.027))$. The initial total renal resistances declined in the enalapril group from $0.2252(0.0679) \mathrm{mm} \mathrm{Hg} / \mathrm{ml} / \mathrm{min}$ to $0.1763(0.0433) \mathrm{mm} \mathrm{Hg} / \mathrm{ml} / \mathrm{min}$ $(\mathrm{p}<0.01)$ but not in the placebo group $(0.2167(0.0898) \mathrm{mm} \mathrm{Hg} / \mathrm{ml} / \mathrm{min}$ to $0.2262(0.1015) \mathrm{mm} \mathrm{Hg} / \mathrm{ml} / \mathrm{min}$. The initial fractional albumin clearance was greater than the control clearance in both groups. At six months it had
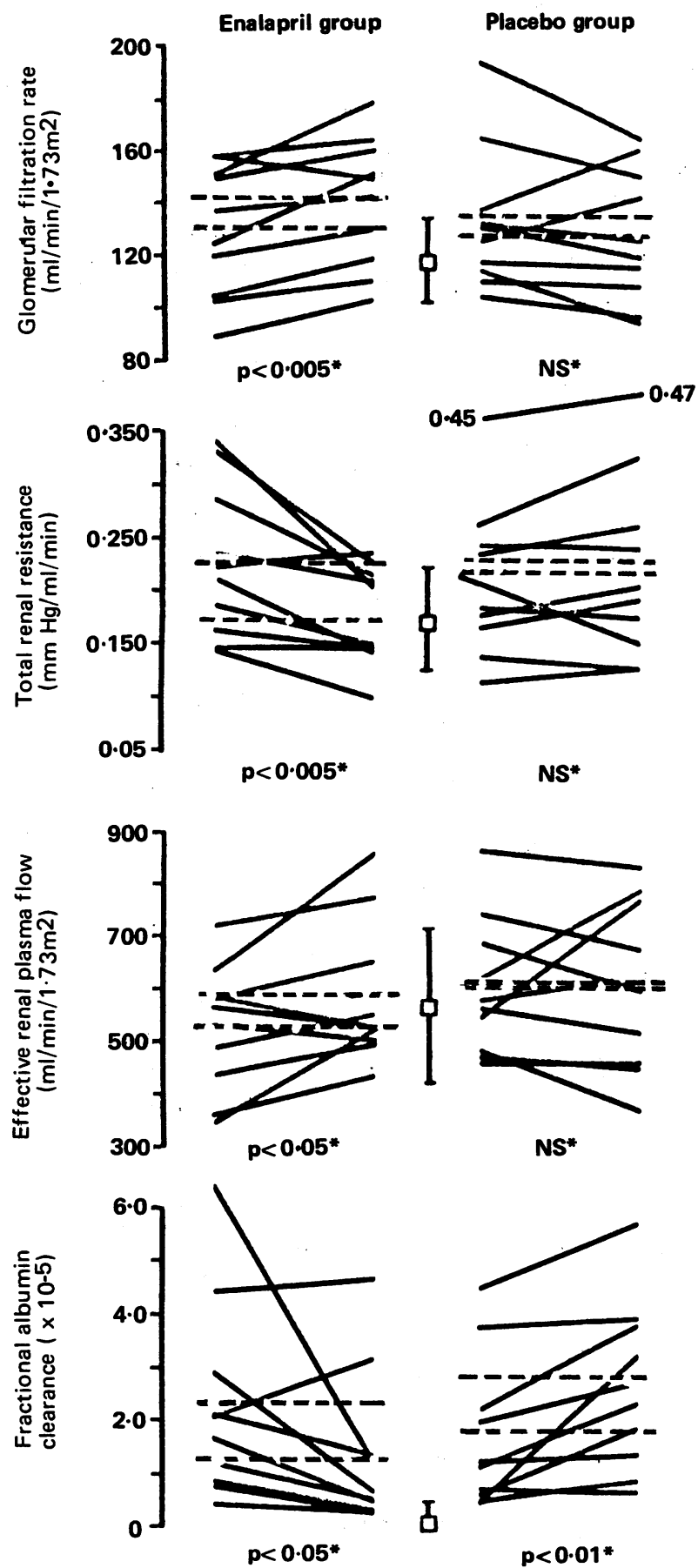

FIG 4-Individual values for glomerular filtration rate (above), total renal resistance (above middle), effective renal plasma flow (below middle), and fractional albumin clearance (below) in enalapril group and placebo group before and after six months of treatment. $----=$ Mean values. $\square=$ Mean control values. Bars represent 2SD. ^ Paired $t$ test. dropped in the enalapril group from $2.25(1 \cdot 79) \times 10^{-5}$ to $1.25(1.40) \times 10^{-5}$ $(\mathrm{p}<0.05)$ but risen significantly in the placebo group from $1.67(1.34) \times 10^{-5}$ to $2.58(1.50) \times 10^{-5}(\mathrm{p}<0.01)$.

\section{Discussion}

In this study a significant decrease in the albumin excretion rate was seen over six months in normotensive diabetic patients who had persistent microalbuminuria and whose blood pressure was being reduced by inhibition of converting enzyme. This was shown by measurements of the albumin excretion rate, which were repeated to allow for variation. ${ }^{28}$ The drop was not caused by improved glycaemic control, as the total proportion of glycosylated haemoglobin remained identical throughout the study in both the enalapril and placebo groups. Neither could it be explained by changes in food intake or protein consumption, ${ }^{34}{ }^{35}$ as the body weight and urinary urea excretion remained stable. The increases in glomerular filtration rate and effective renal plasma flow seen in the enalapril group were accompanied by a reduction in total renal resistance. The concomitant changes in the renin concentrations of these patients suggest good compliance with treatment and effective inhibition of converting enzyme at the times of measurement. As a reduction in the fractional albumin clearance was seen at these times modifications of renal haemodynamics may have reduced glomerular permeability to albumin.

The aim of this work was not to show that near normoglycaemia has a beneficial effect on the course of albumin excretion rate in diabetic patients. In this respect reports concerning type I diabetes are conflicting and suggest that such control is beneficial ${ }^{16}{ }^{18}$ or ineffective. ${ }^{1920}$ As the metabolic condition of the patients studied here was good and stable a reduction in their albumin excretion rate can justifiably be attributed to the connection between albumin excretion rate and variations in blood pressure.

The diabetic patients in this study had initial blood pressures below those defined as signs of mild or moderate hypertension in a general population. ${ }^{36}$ Christensen and Mogensen $e t$ al reported that blood pressure was slightly increased in patients with incipient diabetic nephropathy. ${ }^{23} 37$ They also reported a decrease in the albumin excretion rate of six patients treated with metoprolol, a selective $\beta$ blocker, for a mean period of five years. ${ }^{24}$ Hommel et al reported that the albumin excretion rate of similar patients decreased when their blood pressure was reduced over a short period with clonidine. ${ }^{38}$ In the present study the patients did not have any hypertension, so no lower limit to blood pressure was set as a selection criterion. Nevertheless, the blood pressure of all the patients receiving enalapril decreased after the run in period. The results obtained with this limited number of patients over six months therefore support the notion that in patients who have diabetes with microalbuminuria a long term reduction in their blood pressure can reverse the course of albumin excretion rate.

In diabetes a high glomerular filtration rate frequently occurs after the onset of the disease ${ }^{31}$ and may also occur in incipient diabetic nephropathy. ${ }^{37}$ In this study we found initial hyperfiltration in eight of 20 patients (fig 4), a proportion similar to that reported by Feldt-Rasmussen et al. ${ }^{20} \mathrm{Clinical}$ and experimental evidence shows that in diabetes chronic hyperfiltration is crucial in generating kidney disease. ${ }^{69}{ }^{39}$ This in turn may increase the resistance of the renal vascular bed during subsequent stages of the disease. The significant increase in glomerular filtration rate found here after six months of treatment with enalapril therefore calls for further reflection.

Hollenberg et al reported increases in the glomerular filtration rate when teprotide, an angiotensin I converting enzyme inhibitor, was given over a short period to patients who had essential hypertension. ${ }^{40}$ The increases in glomerular filtration rate and effective renal plasma flow that we observed in patients given enalapril in this study can be attributed to the opening up of additional glomeruli and capillary loops, with a subsequent reduction in renal resistance. ${ }^{41}$ The filtration fraction, however, did not decrease in patients given enalapril in this study, despite angiotensin II acting predominantly on the efferent arteriole. ${ }^{42}$ This may be 
due to the method not being precise enough to measure minimal variations in humans. It is also possible that the afferent and efferent arteriolar resistances were reduced proportionately ${ }^{43}$ or that the glomerular ultrafiltration coefficient increased during inhibition of converting enzyme. ${ }^{26}$

Our results agree with those of Zatz et al, who observed that in normotensive rats who had experimental diabetes reducing the blood pressure with enalapril restricted the intraglomerular pressure and consequently reduced albuminuria but did not alter hyperfiltration. ${ }^{26}$ The reduction in fractional albumin clearance found here after six months of treatment with enalapril suggests that the renal haemodynamic changes discussed above decreased the glomerular permeability to albumin. The concomitant reduction of albumin excretion rate and increase in glomerular filtration rate support the idea that in diabetes the intraglomerular capillary pressure may be more important than hyperfiltration in modifying permeability to albumin.

Nevertheless, the relative importance of the decrease in systemic blood pressure and of the reduction in intraglomerular pressure cannot be analysed separately in our study. Other studies of inhibition of converting enzyme in humans have dealt with hypertensive patients who had diabetic nephropathy; thus Taguma et al reported that in patients with advanced diabetic nephropathy severe proteinuria can be reduced by captopril without affecting the blood pressure and suggested that this drug might also reduce intrarenal hypertension. ${ }^{44}$ Björck et al mentioned increased renal plasma flow and unchanged glomerular filtration rate in similar patients. ${ }^{45}$ Hommel et al reported that in insulin dependent diabetic patients with overt nephropathy albuminuria declined with a reduction in blood pressure after 12 weeks of captopril treatment. ${ }^{46}$ A slight but significant decrease in the glomerular filtration rate was also seen during the same period. An explanation for this apparent discrepancy between Hommel's study and ours could be that autoregulation of the glomerular filtration rate is impaired in overt diabetic nephropathy ${ }^{47}$ but not in incipient nephropathy. ${ }^{38}$

The finding that inhibition of converting enzyme can reduce microalbuminuria in diabetic patients even in the absence of hypertension is promising but should be interpreted with caution. Firstly, the treatment with enalapril lasted for only six months, and longer studies are needed to confirm the beneficial effects of combining inhibition of converting enzyme with antidiabetic treatment in diabetes accompanied by microalbuminuria. Secondly, the potential long term side effects of inhibition of converting enzyme are not yet known. Thirdly, it is not clear whether the reduction in albumin excretion rate seen in this study was due to a reduction in systemic blood pressure independent of the antihypertensive agent used or to specific changes in intraglomerular pressure caused by inhibition of converting enzyme inhibition. Fourthly, the reduction of microalbuminuria can be only an index of the mechanical consequences of the reduction in blood pressure or glomerular pressure, or both, and we do not have any evidence of a proportional reduction in the glomerular lesions. Lastly, the reduction in blood pressure must not prevent studies to find the best possible control of blood glucose: recent data suggest that in insulin dependent diabetes two years of strict glycaemic control can slow down the course of nephropathy. ${ }^{48}$

We are grateful to: Dr Gilles Chatellier from the medical informatics department, Hôpital Pitié-Salpétrière, Paris, for skilful statistical help; Professor Y Najean, Professor J D Rain, and Dr M Leroy from the department of nuclear medicine, Hôpital Saint-Louis, Paris, and to $\mathbf{M r}$ Nuno Luis for technical help; and to Miss Nicole Braure and Florence Lopez for secretarial help. This work was supported by grants from Université Paris VII, from Association Claude Bernard, from the Collège of Médecine des Hôpitaux de Paris, and from Merck Sharp and Dohme, France.

\section{References}

1 Andersen AR, Christiansen JS, Andersen JK, Kreiner S, Deckert T. Diabetic nephropathy in type 1 (insulin-dependent) diabetes: an epidemiological study. Diabetologia 1983;2:496-501.

$2 \mathrm{Kannel}$ WB, McGee DL. Diabetes and glucose tolerance as risk factors for cardiovascular disease: the Framingham study. Diabetes Care 1979;2:120-6.
3 Viberti GC, Hill RD, Jarrett RJ, Argyropoulos A, Mahmud U, Keen H. Microalbuminuria as a predictor of clinical nephropathy in insulin-dependent diabetes mellitus. Lancet 1982:i:1430-2.

4 Parving HH, Oxenboll B, Svendsen PAA, Sandhal Christiansen J, Andersen AR. Farly detection of patients at risk of developing diabetic nephropathy: longitudinal study of urinary albumin of patients at risk of developing diabetic nephropat
excretion. Acta Endocrinol (Copenh) 1982:100:550-5.

5 Mathiesen ER, Oxenboll B, Johansen K, Svendsen PAA, Deckert T. Incipient nephropathy in type 1 (insulin-dependent) dia'betes. Diabetologia 1984;26:406-10

6 Mogensen CE, Christensen CK. Predicting diabetic nephropathy in insulin-dependent patients. NEngl f Med 1984;311:89-93.

7 Mogensen CE. Microalbuminuria predicts clinical proteinuria and early mortality in maturityonset diabetes. N Engl f Med 1984;310:356-60.

8 Viberti GC, Mackintosh D, Keen H. Determinants of the penetration of proteins through the glomerular barrier in insulin-dependent diabetes mellitus. Diabetes 1983;32 suppl 2:92-5.

9 Hostetter TH. Diabetic nephropathy. N Engl f Med 1985;312:642-4.

10 Pirart J. Diabète et complications dégénératives. Présentation d'une étude prospective portant sur 4400 cas observés entre 1947 et 1973. Diabete Metab 1977;3:97-107.

11 Pirart J. Diabète et complications dégénératives. Présentation d'une étude prospective portant sur 4400 cas observés entre 1947 et 1973. Diabete Metab 1977;3:173-82.

12 Pirart J. Diabète et complications dégénératives. Présentation d'une étude prospective portant sur 4400 cas observés entre 1947 et 1973. Diabete Metah 1977;3:245-56.

13 Spiro RG. Search for a biochemical basis of diabetic microangiopathy. Diabetologia 1976:12:1-14.

4 Mauer SM, Steffes MW, Sutherland DER, Najarian JS, Michael AF, Brown DM. Studies of the rate of regression of the glomerular lesion in diabetic rats treated with pancreatic islet transplantation. Diabetes 1975;24:280-5.

15 Abouna GM, Al-Adnani MS, Kremer GD, Kumar SA, Daddah SK, Kusma G. Reversal of diabetic nephropathy in human cadaveric kidneys after transplantation in non-diabetic recipients. Lancet 1983;ii: 1274-6.

16 Viberti GC, Pickup JC, Jarrett RJ, Keen H. Effect of control of blood glucose on urinary excretion of albumin and beta-2-microglobulin in insulin dependent diabetes. $N$ Engl 7 . Med 1979:300: 638-41.

17 Viberti GC, Bilous RW, Mackintosh D, Bending JJ, Keen H. Long-term correction of hyperglycaemia in progression of renal failure in insulin dependent diabetes. $\mathrm{Br}$.Med. $\mathrm{F}$ 1983;286:598-602.

18 Kroc collaborative study group. Blood glucose control and the evolution of diabetic retinopathy and albuminuria: a preliminary multicenter trial. N Engl f Med 1984;311:365-77.

19 Beck-Nielsen H, Richelsen B, Mogensen CE, et al. Effect of insulin pump treatment for one vear on renal function and retinal morphology in patients with IDDM. Diabetes Care 1985:8:385-9.

20 Feldt-Rasmussen B, Mathiesen ER, Hegedus L, Deckert 'T. Kidney function during 12 months of strict metabolic control in insulin-dependent diabetic patients with incipient nephropathy. N Engl f Med 1986;314:665-70.

21 Parving HH, Andersen AR, Smidt UM, Svendsen PAA. Early aggressive antihypertensive treatment reduces rate of decline in kidney function in diabetic nephropathv. Lancet 1983;ii:1175-9.

22 Mogensen CE. Long term antihypertensive treatment inhibiting progression of diabetic nephropathy. BrMed f 1982;285:685-8.

23 Christensen CK. Abnormal albuminuria and blood pressure rise in incipient diabetic nephropathy induced by exercise. Kidney Int 1984;25:819-23.
intistensen

24 Christensen CK, Mogensen CE. Effect of antihypertensive treatment on progression of incipient diabetic nephropathy. Hypertension 1985;7:9-13.

25 Friedman PJ, Dunn PJ, Jury DR. Metoprolol and albumin excretion in diabetes. Lancet $1986 ;$ ii: 43 .

26 Zatz R, Dunn BR, Meyer TW, Anderson S, Rennke HG, Brenner BM. Prevention of diabetic glomerulopathy by pharmacological amelioration of glomerular capillary hypertension. $7 \mathrm{Clin}$ Invest 1986;77:1925-30.

27 Passa P, Leblanc H, Marre M. Effects of enalapril in insulin-dependent diabetic subjects with mild to moderate uncomplicated hypertension. Diabetes Care 1987;10:200-4.

28 Feldt-Rasmussen B, Mathiesen ER. Variability of urinary albumin excretion in incipient diabetic nephropathy. Diabetic Nephropathy 1984;3:101-3.

29 Christensen CK, Orskov C. Rapid screening PEG radioimmunoassay for quantification of pathological albuminuria. Diabetic Nephropathy 1984;3:92-4

30 Viberti GC, Mogensen CE, Keen H, Jacobsen FK, Jarrett RJ, Christensen CK. Urinary excretion of albumin in normal man. The effect of water loading. Scand f Clin Lab Invest 1982:42:147-51.

31 Mogensen CE. Glomerular filtration rate and renal plasma flow in short-term and long-term juvenile diabetes mellitus. Scand F Clin Lab Invest 1971;28:91-100.

32 Ménard J, Guyenne T, Corvol P, Pau B, Simon B, Roncucci R. Direct immunometric assay of active renin in human plasma. $\mathcal{F}$ Hypertension 1985;3(suppl 3):275-8

33 Winer BJ. Staistical analysis in experimental design. 2nd ed. New York: McGraw-Hill, 1971

34 Vasquez B, Glock EV, Savage PJ, et al. Sustained reduction of proteinuria in type 2 non-insulindependent) diabetes following diet induced reduction of hyperglycaemia. Diabetologia 1984;26: 127-33.

35 Brenner B, Meyer TW, Hostetter T. Dietary protein intake and the progressive nature of kidney disease. N Engl f Med 1982;307:652-9.

36 Joint National Committee on detection, evaluation and treatment of high blood pressure. The 1984 report of the joint national committee on detection, evaluation and treatment of high blood pressure. Arch Intern Med 1984;144: 1045-7.

37 Mogensen CE, Christensen CK, Vittinghus E. The stages in diabetic renal disease. With emphasis on the stage of incipient nephropathy. Diabetes 1983;32(suppl 2):64-78.

38 Hommel E, Mathiesen E, Edsberg B, Bahnsen M, Parving HH. Acute reduction of arterial blood pressure reduces albumin excretion in type 1 (insulin-dependent) diabetic patients with incipient nephropathy. Diabetologia 1986;29:211-5.

39 Hostetter TH, Rennke HG, Brenner BM. The case for intrarenal hypertension in the initiation and progression of diabetic and other glomerulopathies. Am J Med 1982;72:375-80.

40 Hollenberg NK, Swartz SL, Passan DR, Williams GH. Increased glomerular filtration rate after converting-enzyme inhibition in essential hypertension. N Engl f Med 1979;301:9-12.

41 Ichikawa I, Brenner BM. Glomerular actions of angiotensin II. Am f Med 1984;76:43-9.

42 Hall JE, Guyton AC, Jackson TE, Coleman TG, Lohmeier TE, Tripoddo NC. Control of glomerular filtration rate by renin-angiotensin system. Am f Physiol 1977;233:F366-72.

43 Navar LG, Rosivall $L$. Contribution of the renin-angiotensin system to the control of intrarenal hemodynamics. Kidney Int 1984;25:857-68.

44 Taguma Y, Kilamoto Y, Futaki G, et al. Effect of captopril on heavy proteinuria in azotemic diabetics. N Engl f Med 1985;313:1617-20.

45 Björck S, Nyberg G, Mulec H, Granerus G, Herlitz H, Aurell M. Beneficial effects of angiotensin converting enzyme inhibition on renal function in patients with diabetic nephropathy. Br.Medf 1986;293:471-4

46 Hommel E, Parving HH, Mathiesen E, Edsberg B, Nielsen MD, Giese J. Effect of captopril on kidney function in insulin dependent diabetic patients with nephropathy. $\mathrm{Br}$ Med 7 1986;293:467-70

47 Parving HH, Kastrup H, Smidt UM, Andersen AR, Feldt-Rasmussen B, Sandahl-Christiansen J. Impaired autoregulation of glomerular filtration rate in type I (insulin-dependent) diabetic patients with nephropathy. Diabetologia 1984;27:547-52.

48 Feldt-Rasmussen B, Mathiesen ER, Deckert T. Effect of two years of strict metabolic control on progression of incipient nephropathy in insulin-dependent diabetes. Lancet 1986:ii:1300-4.

(Accepted 16 March 1987) 